\title{
Sustainable Environment and Tourism Industry: An Institutional Policy Analysis of Northeastern Thailand
}

\author{
Juan Carlos Calderon Lopez ${ }^{1,2 *}$, Kampanad Bhaktikul ${ }^{1}$ \\ ${ }^{1}$ Faculty of Environment and Resource Studies, Mahidol University, Nakhon Pathom, 73170, Thailand \\ ${ }^{2}$ Agricultural Research Faculty, Dr. José Matías Delgado University, El Salvador
}

Received: 12 April 2017

Accepted: 21 June 2017

\begin{abstract}
The aim of this research is to evaluate and assess the tourism policies and environmental sustainability related to the tourism industry in the Khon Kaen province of Thailand. The tourism industry is one of the greatest contributors to gross domestic product (GDP) in Thailand. Therefore, the relationship of tourism with the three pillars of sustainable development, i.e., economic, environmental, and social, is very important. To analyze the situation we used qualitative and quantitative approaches. Likewise, primary and secondary data were collected using different sets of tools. Moreover, we applied different statistical models and tests such as the Friedman scale method, Range table analysis, and multiple comparison ranks. Our results showed that Khon Kaen was a good contributor to the economy of Thailand. The analysis showed that the highest percentage (26\%) of activities was related to hiking of mountain areas. Nonetheless, museums and educational parks ranked second with $20 \%$ followed by temples at $14 \%$. National parks represented $11 \%$ of the total attraction spots. Local policy makers need to design a sustainable tourism policy framework while keeping in view the sustainable environment. Coordination among public and private sectors may also help to promote a sustainable tourism industry.
\end{abstract}

Keywords: environment, sustainability, tourism dynamics, statistical analysis, SWOT analysis, Thailand

\section{Introduction}

According to Martin Mowforth and Ian Munt's Tourism and Sustainability (2007: 2), it is believed that tourism is associated with the concept of sustainability, i.e., environmental, economic, and socio-cultural components. Thus, it is even more important to understand the roles of social, cultural, economic, and political gears in the development and advancement of the tourism

*e-mail: juancarlos.cal@mahidol.ac.th industry [1]. Tourism development does not simply equate with economic growth, but rather development in a broader sense. While the term "sustainable tourism" is controversial and has been defined in different ways, it appears that the foci of economic impact and growth need to be broadened through the inclusion of social, environmental, and cultural effects [2]. International tourist arrivals grew by $4 \%$ between January and August 2015, compared with the period of 2012-14, according to the World Tourism Organization (WTO). Also, the number of international tourists in the world grew by $4 \%$ between January and August 2015, compared to the same 
years as of 2012-14 (28 million). With a record of 705 million tourists until August 2015, the WTO hopes that by the end of this year, one billion international tourists will have traveled the world [3]; thus, this plan has highlighted the importance of tourism, which reached a figure of 19.5 million international travelers in 2015. This represents an increase of almost $20 \%$ as compared to the previous year [4]. When comparing the total amount of revenue generated from global tourism, which is stated as approximately U.S\$ 24.85 million, domestic tourism would also rise to over 80-93 million trips during the same time period, which is an increase of over $16 \%$. In looking at the aforementioned statistics as indicators of economic growth, Thailand would thus be able to generate an estimated total revenue of approximately 453 billion Thai Baht (THB; equivalent to $\$ 14.5$ billion U.S.), thus showing steady growth after the floods in Thailand [5].

Khon Kaen recently became a popular tourist destination and has contributed well to the gross provincial product (GPP). However, concrete information and data are unavailable to determine its contribution to the economy, environmental impacts, and systemic flaws of the Thai system. Several researchers have studied tourism and the tourist industry with attention to multiple study areas and countries. For example, see [6-12] for an extensive discussion of the tourist industry in developing countries. Moreover, some studies have discussed international visitors' movements [6, 13-15].

However, none of them have discussed the tourism industry related to institutional policy analysis in Khon Kaen, and no evidence has been found regarding any potential statistical approaches to conducting such an analysis of the literature. In spite of this, the Tourism Authority of Thailand has recently launched ambitious strategic plans to increase tourism in the Asian region, especially in Thailand. These plans comprise the annual action plan marketing through TAT. Moreover, the marketing action plan aims to stimulate growth by taking into account the rapid changes in tourism and the changes that have occurred in recent years. In addition, this plan also considers newly emerging markets, the popularity of social media, consumption driven by technology, and an increasing worldwide demand for sustainable and environmentally friendly products, as this is a strategy that takes the variations in the tourism sector into consideration, which is in a state of constant and relentless change. Therefore, the main aim of this research is to evaluate and assess the tourism policies and environmental sustainability related to the tourism industry in Khon Kaen province of Thailand.

\section{Methodology}

\section{Study Area}

Khon Kaen Province was selected as the study area. Khon Kaen is located in northeastern Thailand between $15-17^{\circ}$ north latitude and $100-103^{\circ}$ east longitude. It encompasses almost $10,885.99 \mathrm{~km}^{2}$. The administrative boundary is divided into 26 districts (Amphoe), 198 communes (tambon), and 2,139 villages (muban).

\section{Data Collection}

This study implemented both qualitative and quantitative approaches in collecting information. Both primary and secondary data were collected. The primary data was obtained through a questionnaire survey and a hedonic test in the tourist hotspots (hotels and restaurants). Moreover, field observation was another set of information. Secondary data were collected in the form of a literature review of existing data and information on both published and unpublished accounts.

\section{Modeling and Statistical Analyses}

The hedonic model, Friedman Test, and other statistical methods such as t-test, $\chi^{2}$ test, and econometric functions were used to investigate the results. Details of these models/tests are given below. The data consist of "k"-related samples (corresponding to " $k$ " treatments), each of size "b" (number of blocks). Rank 1 is assigned to the smallest observation, 2 to the second and then until the largest of the " $k$ " observations within each block. In the case of a tie, we use the average of the ranges corresponding. Calculate $\mathrm{R}_{\mathrm{i}}$ for each sample (treatment):

$$
R_{i}=\sum_{j=1}^{b} R\left(X_{i j}\right)
$$

...where $\mathrm{R}(\mathrm{X} \mathrm{ij})$ is the rank assigned to observation $\mathrm{Xij}$ inside block " $\mathrm{j}$," and where $\mathrm{Ri}$ is the sum of the ranks assigned to sample $i$.

\section{Assumptions}

1. The "b" blocks are mutually independent (results within a block do not influence the results in others).

2. The scale is at least ordinal so that observations are arranged within each block.

\section{Hypothesis Test Process}

Hypothesis: $\mathrm{H}_{0}$ : There is no significant difference between treatments (tourism policy)

$\mathrm{H}_{1}$ : At least one of the treatments has a different effect.

Test statistic: First, calculating the values of the parameters $\mathrm{A}$ and $\mathrm{B}$ :

$$
A=\sum_{i=1}^{k} \sum_{j=1}^{b}\left[R\left(X_{i j}\right)\right]^{2}
$$




$$
B=\frac{1}{b} \sum_{i=1}^{k} R_{i}^{2}
$$

$$
\text { proof or } T \text { or } F r=\frac{(k-1)\left[b B-\frac{b^{2} k(k+1)^{2}}{6}\right]}{A-\frac{b k(k+1)^{2}}{6}}
$$

The standard decision rule is followed as in similar studies [16-18].

\section{Application of the Friedman Test for Each Characteristic}

Being a: the significance level and $\mathrm{v}=(\mathrm{b}-1)$ (k-1) degrees of freedom of the comparison test. We subsequently presented the following statistical operations applied to the results of the tests of policy analysis of Khon Kaen tourist for this research using the Friedman method mentioned above. Note that each product (Policy, PT-1 = Policy of Tourism 1, PT-2 = Policy of Tourism 2 thereby successively until PT 6) are analyzed treatments that are presented below.

\section{Statistical Test or $\chi^{2}$ Proof}

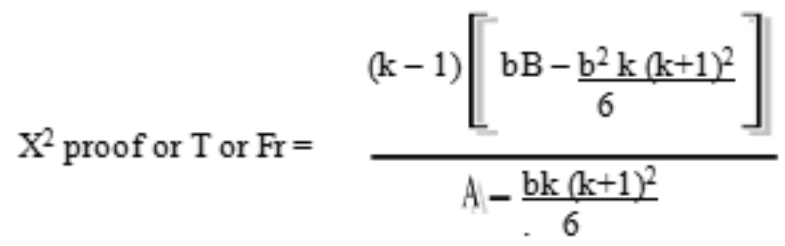

$$
\text { Critical Statistical Fr }{ }_{\text {Critical }} \text { or } \chi_{\text {critical }}^{2}
$$

The Critical value of the statistic for a significance level of $5 \%$, where:

$v=0.05(5 \%)$

$\alpha=(\mathrm{k}-1)(6-1)$

$\alpha=5$

$\chi_{\text {critical }}^{2} 0.005,5=11.07$

\section{Results and Discussion}

This section explains the results and significant findings of this study. The tourism development authority of Khon Kaen is mostly handled by two organizations: the Office of Tourism and Sports in Khon Kaen Province, which belongs to the Thai Ministry of Tourism and Sports; and the Tourism Authority of Thailand. Policy analysis of tourism management and development is explained in subsequent sections. Fig. 1 is presenting the statistical results of the findings.

\section{Experimental Design of Tourism Policies}

The experimental design was to determine acceptability or compliance with policies related to tourism. To find out whether a policy is reaching its function or if it is being implemented according to the terms, the experimental design consisted of six policy options to evaluate the major sectors involved (i.e., hotels and restaurants). The main respondents were hotel managers, owners, etc. To figure out the tourism policy of Khon Kaen, the Friedman test was taken into consideration and adapted from [18-20] using parametric and non-parametric tests. The codes and policy evaluations are:

- Tourism Policy $1=$ TP 1: To promote tourism at international and domestic levels.

- TP 2: To promote and develop a tourism support infrastructure, improve the level of safety and hygiene facilities, and enable access to the destinations by disabled and elder people.

- TP 3: To promote, develop, restore, and revive the environment and natural resources; moreover, to solve environmental and related problems.

- TP 4: To promote a quality tourist market.

- TP 5: To promote value-added tourism services and standards.

- TP 6: To promote integrity and cooperation, and improve the effectiveness of law enforcement to facilitate tourism and the development of a sustainable tourism industry.

\section{Findings from Statistical Analysis}

Using statistical tests and methods as explained earlier, the following results have been drawn on the basis of the analyses and findings of this study. Table 1 shows the policy range table results for each policy. The hypotheses to be tested were:

$-\mathrm{H}_{\mathrm{o}}$ : The six treatments or policies have the same effects.

- $\mathrm{H}_{1}$ : At least one of the treatments or policies has a different effect in terms.

- Allocation ranges: from low to high within each block (Judge).

Rank 1 will be assigned to the smaller range, with the second range taking 2 , and so on. Consequently, 6 was used in the case of a tie. After assigning the ranges $\mathrm{R}$ (Xij), the range assigned to the observation $\mathrm{Xij}$ inside block " $\mathrm{j}$ " obtained Ri, which is the sum of the ranges assigned to sample "i." This means that the current administration of Khon Kaen promotes both domestic and international tourism through the development of tourism and tourist destinations, in addition to ensuring the safety of travelers. Furthermore, support for ecotourism, cultural tourism, and health tourism are also significant policy goals of the authorities. The current administration is also promoting value added services to the Khon Kaen tourism sector in order to improve the quality of tourism services, such as by promoting 
Table 1. Assessment scale Friedman method-policy range table.

\begin{tabular}{|c|c|c|c|c|c|c|}
\hline & $\begin{array}{c}\text { Policy } \\
1\end{array}$ & $\begin{array}{c}\text { Policy } \\
2\end{array}$ & $\begin{array}{c}\text { Policy } \\
3\end{array}$ & $\begin{array}{c}\text { Policy } \\
4\end{array}$ & $\begin{array}{c}\text { Policy } \\
5\end{array}$ & $\begin{array}{c}\text { Policy } \\
6\end{array}$ \\
\hline No. & PT 1 & PT 2 & PT 3 & PT 4 & PT 5 & PT 6 \\
\hline 1 & 2.5 & 5 & 2.5 & 2.5 & 6 & 2.5 \\
\hline 2 & 3 & 3 & 3 & 3 & 6 & 3 \\
\hline 3 & 4.5 & 6 & 4.5 & 1.5 & 3 & 1.5 \\
\hline 4 & 2 & 1 & 4 & 4 & 6 & 4 \\
\hline 5 & 4 & 4 & 1.5 & 1.5 & 4 & 6 \\
\hline 6 & 4.5 & 2 & 2 & 4.5 & 2 & 6 \\
\hline 7 & 3.5 & 6 & 3.5 & 3.5 & 1 & 3.5 \\
\hline 8 & 4 & 4 & 4 & 2 & 2 & 2 \\
\hline 9 & 3.5 & 3.5 & 3.5 & 3.5 & 3.5 & 3.5 \\
\hline 10 & 6 & 3 & 3 & 3 & 3 & 3 \\
\hline 11 & 5 & 2.5 & 5 & 2.5 & 1 & 5 \\
\hline 12 & 3.5 & 3.5 & 3.5 & 3.5 & 3.5 & 3.5 \\
\hline 13 & 3.5 & 1.5 & 3.5 & 5 & 6 & 1.5 \\
\hline 14 & 1.5 & 1.5 & 4.5 & 4.5 & 6 & 3 \\
\hline 15 & 2 & 6 & 2 & 2 & 4.5 & 4.5 \\
\hline 16 & 4.5 & 4.5 & 2.5 & 6 & 1 & 2.5 \\
\hline 17 & 1 & 5 & 5 & 2.5 & 2.5 & 5 \\
\hline 18 & 5.5 & 3.5 & 5.5 & 3.5 & 1.5 & 1.5 \\
\hline 19 & 5 & 2.5 & 2.5 & 2.5 & 6 & 2.5 \\
\hline 20 & 5 & 2 & 5 & 1 & 5 & 3 \\
\hline Ri & 74 & 70 & 70.5 & 62 & 73.5 & 67 \\
\hline
\end{tabular}

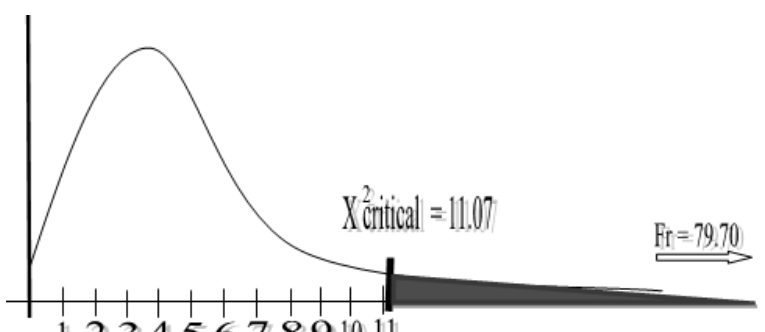

1234567891011

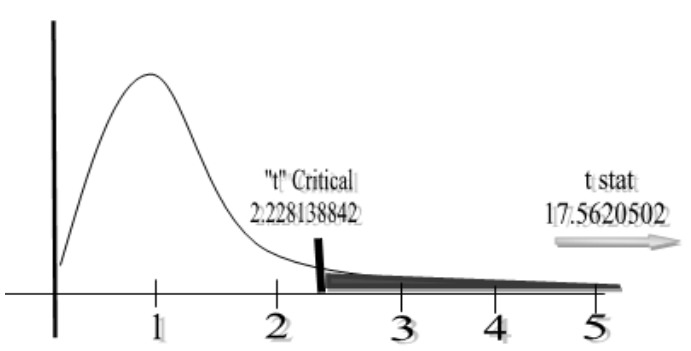

Fig. 1. Statistical test results of the analysis.
Thailand as a movie industry location, and supporting the candidacy of Thailand to host international events.

As Fr is higher than critical $\chi 2 \quad(79.70>11.07)$, the null hypothesis (H0) is rejected. This means that the hypothesis is rejected and rest one is accepted. Therefore, the next step is to use multiple comparisons to evaluate each of the policies and compare them against each other.

\section{Multiple Comparisons}

As Ho is rejected, the Friedman test provides a method for comparing treatments in pairs [18]. This method helps to compare treatments "I" and " $\mathrm{j}$ " to find the significance or how values differ from each other:

$$
\left|R_{i}-R_{j}\right|>t_{\frac{\alpha}{2}}, v \cdot \sqrt{\frac{2 b(A-B)}{(b-1)(k-1)}}
$$

$\frac{\alpha}{2}=$ Area of the right tail $\frac{\alpha}{2}=\frac{0.05}{.2}=\underline{0.025}$

Degrees of Freedom for t paired test:

$v=(b-1)(k-1)$

$v=(20-1)(6-1)$

$v=95$

Then it searches the data in the table student $t$ test:

t $0.025,95=2.00$

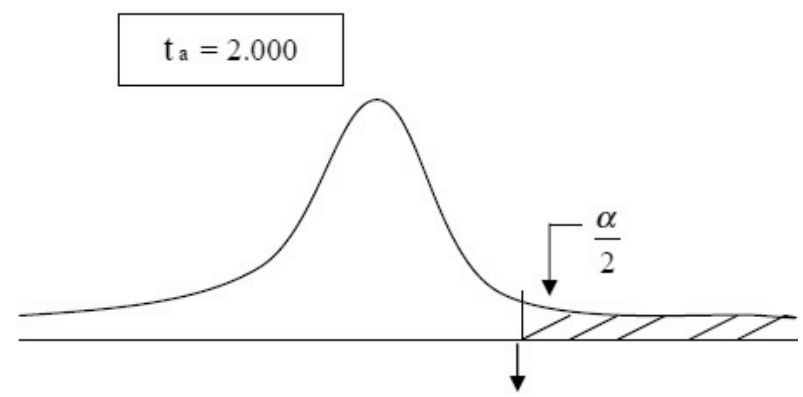

t $0.025,95=2.00$

$R$ critical $=\mathbf{1 0 . 1 1}$

There is no doubt that the development of tourism as a key strategic pillar is the right decision for the country's economic growth. However, to achieve sustainable tourism, there must be coordination between the public and private spheres that involves every player of the industries involved. For this study, it is necessary to examine and analyze the relationship of Khon Kaen's gross domestic product (GDP) with tourism. Table 2 explains the information collected and analyzed from TAT Khon Kaen. In total, $26 \%$ of tourism activities are related to hiking in mountain areas; this segment of the tourism industry represents the highest contribution to the tourism segment of Khon Kaen's GDP. Museums and educational parks rank second at 20\%. Finally, 11\% of tourism activities relate to national parks - another popular attraction in the province. Khon Kaen has many parks, each fulfilling different potential tourist objectives 
Table 2. Potential tourism activities in Khon Kaen.

\begin{tabular}{|c|c|c|c|c|c|c|c|c|c|c|c|c|}
\hline \multicolumn{2}{|r|}{ Types of tourism } & \multicolumn{9}{|c|}{ Implementing } & \multicolumn{2}{|c|}{ Amphoe } \\
\hline \multirow{5}{*}{$\begin{array}{l}\text { Adventure } \\
\text { Travel }\end{array}$} & Camping & & & & & & & & & & $\begin{array}{l}\text { 1.Mueang Khon } \\
\text { Kaen }\end{array}$ & $\begin{array}{l}\text { 22. Khok Pho } \\
\text { Chai }\end{array}$ \\
\hline & Climbing & & & & & & & & & & 2.Ban Fang & $\begin{array}{l}\text { 23. Nong } \mathrm{Na} \\
\text { Kham }\end{array}$ \\
\hline & Cycling & & & & & & & & & & 3.Phra Yuen & 24.Ban Haet \\
\hline & Hiking & & & & & & & & & & 4.Nong Ruea & 25.Non Sila \\
\hline & Mountaineering & 5 & 5 & 5 & $5-\mathrm{C}$ & $5 \mathrm{wf}$ & $5 \mathrm{wf}$ & $5 \mathrm{cv}$ & $20 \mathrm{cv}$ & 20 & 5.Chum Phae & 29.Wiang Kao \\
\hline \multirow{7}{*}{$\begin{array}{l}\text { Cultural } \\
\text { Tourism }\end{array}$} & Gastronomic Tourism & 1 & & & & & & & & & 6.Si Chomphu & \\
\hline & $\begin{array}{c}\text { Museums and educational } \\
\text { parks } \\
\end{array}$ & 1 & 7 & 19 & 29 & 5 & 18 & 10 & & & 7.Nam Phong & \\
\hline & Grand tour & & & & & & & & & & 8.Ubolratana & \\
\hline & Cinematic tourism & & & & & & & & & & 9.Kranuan & \\
\hline & Monuments & 1 & 7 & & & & & & & & 10.Ban Phai & \\
\hline & Literary tourism & & & & & & & & & & 11.Pueai Noi & \\
\hline & Ruins or older edification & 5 & 7 & 11 & & & & & & & 12.Phon & \\
\hline Ecotourism & National parks & 4 & 19 & 29 & 5 & & & & & & 13.Waeng Yai & \\
\hline $\begin{array}{l}\text { Medical } \\
\text { Tourism }\end{array}$ & Medical tourism & & 7 & & & & & & & & 14.Waeng Noi & \\
\hline \multirow{5}{*}{$\begin{array}{l}\text { Rural } \\
\text { Tourism }\end{array}$} & Agritourism & $17 \mathrm{t}$ & 17 & & & & & & & & $\begin{array}{l}\text { 15. Nong Song } \\
\text { Hong }\end{array}$ & \\
\hline & Therianos villas & & & & & & & & & & 16.Phu Wiang & \\
\hline & Farmstays & & & & & & & & & & 17.Mancha Khiri & \\
\hline & Ethnotourism & & 7 & & & & & & & & 18.Chonnabot & \\
\hline & Forestar & & & & & & & & & & $\begin{array}{l}\text { 19. Khao Suan } \\
\text { Kwang }\end{array}$ & \\
\hline \multirow{2}{*}{$\begin{array}{l}\text { Religious } \\
\text { tourism }\end{array}$} & Temples & 1 & 19 & 17 & 22 & 15 & & & & & 20.Phu Pha Man & \\
\hline & $\begin{array}{c}\text { Relious activities or } \\
\text { festivals }\end{array}$ & & & & & & & & & & 21.Sam Sung & \\
\hline \multirow{3}{*}{$\begin{array}{l}\text { Event and } \\
\text { Festivals }\end{array}$} & Songkran All & & & & & & & & & & & \\
\hline & $\begin{array}{l}\text { Phrarthat Kham Kaen Fair } \\
\text { in Amphoe Mancha khiri }\end{array}$ & & & & & & & & & & & \\
\hline & Silk Festival & & & & & & & & & & & \\
\hline
\end{tabular}

such as culture, education, forestry, and the environment. Notably in Thailand, temples are a particularly popular attraction, representing $14 \%$ of the total tourism industry. In fact, the attraction of archeological buildings classified as "national ancient monuments" represent $6 \%$ of total tourism activities. Our results are similar to the findings of [21-23].

\section{SWOT Analysis of Tourist Policies and Attractions}

A strengths, weaknesses, opportunities, and threats (SWOT) analysis is used especially in strategic planning as a simple way to identify the elements that act as "tractor" economic and territorial development (to strengthen a plan), and the elements that act as a brake or drag (to drag down the plan) [24]. A comprehensive SWOT analysis is presented below for the tourism industry in Khon Kaen province:

\section{Strengths}

- Geographic location as the export center for trade in the Indochina region.

- Ancient historical richness (origins of Thailand's civilization).

- Archaeological museum dinosaur fossil.

\section{Weaknesses}

- Lack of support from the government tourism sector (provincial level). 
- Lack of tourism development initiatives.

- Lack of interaction with foreigners (low English language proficiency levels in government and private sectors).

- Unskilled transportation system to promote tourism.

- Lack of marketing and involvement of stakeholders.

\section{Opportunities}

- Geography (mountainous and natural resources, waterfalls, lakes, mountains, forest areas).

- Easy accessibility due to the ease of travel from the capital to the province (6-7 hours by bus, 40 minutes by plane, 3-4 hours by car).

- Ideal infrastructure (restaurants, hotels, roads, hospitals, communication systems, transportation).

- Traditions and gastronomy unique to the province.

\section{Threats}

- Probability of increased prostitution.

- Impairment of natural resources.

- Increased pollution of rivers and lakes.

\section{Conclusions}

This study sought to analyze tourist polices and environmental issues related to the tourist industry in Thailand's Khon Kaen Province. Different methods, tests, and tools were utilized to analyze a set of policies (hypotheses). The study identified problems through analyses. They included the lack of the promotion of tourism in the province. It was concluded that, unlike the three major Thai tourist destinations that were evaluated in this research (Phuket, Chiang Mai, Bangkok), Khon Kaen was not among the top five tourist destinations. Hence, this research analyzed and investigated multiple points, for instance, the lack of marketing, the lack of public-private coordination, being a mountainous area only, and having fewer attractions than the other places. However, this province has significant potential to become one of the nation's top five tourist destinations if policy action plans are implemented effectively. It has also been found that Khon Kaen contributes to the GDP of the country and the GPP of the province through the tourist industry. It is recommended that the local policy makers need to design a robust and effective tourism promotion action plan to improve the influx of local and foreign tourists. Moreover, it is also suggested that a sustainable and clean environment may also help to improve sustainable tourism in the province.

\section{References}

1. WU W., ZHANG X., YANG Z., QIN W., WANG F., WANG C. Ecotourism Suitability and Zoning from the Tourist Perspective : a Nature Reserve Case Study. Polish Journal of Environmental Studies, 24 (6), 2683, 2015.

2. HANSEN B.E. Test for parameter instability in regressions with 1 processes, Journal of Business and Economic Statistics, 10 (3), 321, 2012.
3. Khon Kaen Provincial office. Khon Kaen Provincial development plan 2011-2014. Available online on http://www.khonkaen.go.th/khonkaen6/StratergyDB/ MainFrame.html, Accessed on February, 2017.

4. TOURISM Authority of Thailand. Tourism Statistics, (Available online: http://www2.tat.or.th/stat/web/static_ download.php?Rpt=nmt. Accessed on June, 2016.

5. OIE. The Office of the Industrial Economics and Bank of Thailand. Report compiled by Energy Policy and Planning Office of Thailand, Bangkok, Thailand, 2016.

6. ABBAS T., ALI G., ADIL S.A., BASHIR M.K., KAMRAN M.A. Economic Analysis of Biogas Adoption Technology by Rural Farmers: A Case of District Faisalabad, Pakistan. Renewable Energy, 107, 431, 2017.

7. ALI G., BASHIR M.K., ALI H., BASHIR M.H. Utilization of Rice Husk and Poultry Wastes for Renewable Energy Potential in Pakistan: An Economic Perspective. Renewable and Sustainable Energy Reviews, 61, 25, 2016.

8. ALI G., ABBAS S. Exploring $\mathrm{CO}_{2}$ sources and sinks nexus through integrated approach; insight from Pakistan. Journal of Environmental Informatics, 2 (22), 112, 2013.

9. HENKEL R., HENKEL P., AGRUSA J., TANNER J. Thailand as a tourist destination: Perceptions of international visitors and Thai residents. Asia Pacific Journal of Tourism Research, 11 (3), 269, 2006.

10. ROTARU L., CIMPOESU D., FORTOFOIU M. Determinism, coincidental or multiple concurrent ischemic events in severe hypothermia - Case report. Jokull, 63 (7), 106, 2013a.

11. ROTARU L., FORTOFOIU M., FORTOFOIU M.C., POPA, O., CIULU C.V., CIMPOESU D. Emergency intervention in burn mass casualty. Jokull, 63 (12), 82, 2013b.

12. RUSSELL R., FAULKNER B. Entrepreneurship, chaos and the Tourism Area Lifecycle, Tourism Management, 31 (3): $556,2004$.

13. OLIVIER D. "Tourism and Power" Universidad de las Antillas y de Guayana - Geode Caribe, 2004.

14. KACZOR, G., BERGEL, T., BUGAJSKI, P., PIJANOWSKI, J. Aspects of Sewage Disposal from Tourist Facilities in National Parks and Other Protected Areas. Polish Journal of Environmental Studies, 24 (1), 107, 2015.

15. FILIPIAK-FLORKIEWICZ A., TOPOLSKA K. Are Environmental Contaminants Responsible for " Globesity"?, 26 (2), 467, 2017.

16. WAGNER A., ORLEWICZ-MUSIAŁ M. Functions and Dysfunctions of Tourism and Recreation and How They Influence Aquatic Environments. Polish Journal of Environmental Studies, 23 (3), 1045, 2014.

17. FRIEDMAN M. The Use of Ranks to Avoid the Assumption of Normality Implicit in the Analysis of Variance. Published by: American Statistical Association, 2008.

18. KNAFOU R., STOCK M. Tourism, in Lévy J. \& Lussault M. (dir.), Dictionnaire de la géographie et de l'espace des sociétés, Paris, 931, 2003.

19. LEE C.C., CHANG C.P. Tourism development and economic growth: A closer at panels, Tourism Management, 29 (1), 180-192, 2008.

20. LICKORISH J.L., JENKINS L.C. Introduction to Tourism. Melbourne: Reed Educational and Professional Publishing. ISBN 075061956 2, 1997.

21. MCGREW A. The state in advanced capitalist countries. in J Allen, P. Braham and P Lewis (eds) Political and Economic Forms of Modernity, Oxford: Polity Press, 1992. 
22. ALI G., ABBAS S., QAMER F.M. How Effectively Low Carbon Society Development Models Contribute in Climate Change Mitigation and Adaptation Action Plans in Asia. Renewable and Sustainable Energy Reviews, 26, 632, 2013.
23. National Statistics Office of Thailand. Ministry of Information and Communication Technology. Available online on: http://web.nso.go.th/ Accessed on June, 2016.

24. WORLD Bank. The World Bank Perspectives on Development. The Creative World. New York, USA, 2002. 